\title{
Performance analysis of a basin-type solar still during harmattan
}

\author{
Omololu D. Ogunseye ${ }^{1}$, Kamar T. Oladepo ${ }^{2}$ \\ ${ }^{1}$ Technical Services - Tailings \& Water, Freeport McMoRan Inc., Arizona, 80054, USA \\ ${ }^{2}$ Civil Engineering Department, Obafemi Awolowo University, Ile-Ife, Nigeria
}

5 Correspondence to: Omololu D. Ogunseye (omololu.ogunseye@outlook.com)

\begin{abstract}
This study investigates the variational effect of climate factors on the productivity of a basin-type solar still during the harmattan season under the tropical savanna climate. The study was extended to examine the influences of selected climatic, operational, and design (COD) parameters on productivity. Additionally, the efficiency of solar still in removing water impurities during harmattan was also investigated. Explorative data and statistical analysis, and laboratory testing methods

10 were used for these investigations. Results show that seasonal effects of harmattan can either increase or lower productivity. The effect of wind speed on productivity was not clearly defined during the harmattan season. Although high irradiation is essential for increased productivity, its effect is modified by other factors. Water temperature is the most significant to productivity amongst selected factors studied via the design of experiment (DOE). Moreover, the effect of harmattan on the water quality produced was not established. The main contribution of this work is the insights generated for both qualitative

15 and quantitative reliability performance of a basin-type solar still under prevailing climate conditions.
\end{abstract}

\section{Introduction}

Water occupies $70 \%$ of the earth's total area but exists in not directly usable forms. Out of the $3 \%$ that occur as fresh and brackish water, only a fraction is in liquid form (Pfafflin and Ziegler, 2006). Economic extraction of usable freshwater driven by a growing population has led to shortages in freshwater supply (Boretti and Rosa, 2019). Apart from the growing population,

20 pollution of freshwater reserves has worsened shortages and led to the spread of diseases from consuming contaminated water (Egarievwe et al., 1991). Desalination can improve water quality (W.R McCluney, 1984); however, it is highly energyconsuming. Renewable energy sources are viable low-cost options. Pfafflin and Ziegler (2006) stated that solar energy is the most promising renewable energy source because of its abundance and significantly low long-term cost. The use of solar distillation to purify contaminated water is appropriate for small-scale water supply (Egarievwe et al., 1991), especially in low 25 populated areas and in emergencies.

Single basin-type is the most proven solar still device used for solar distillation because of its simplicity (Velmurugan and Srithar 2011). It consists of a basin pan covered with transparent glass. When the absorption of solar energy heats the water in the basin, its temperature rises, and water molecules are liberated. Convection air above the water surface carries the vapor molecules to the relatively low-temperature cover, condensing due to temperature gradient. Carrier air is cooled due to the release of latent heat of condensation. The cooled air then returns to the water surface to push more vapor molecules towards 
the cover (Abdelkader, 2006). Solar distillation was first used on a significant scale about 1872 in Chile. It is often classified as an active or passive type based on the energy supply (Aybar, 2007). Active solar still requires additional components to supply extra thermal energy to hasten evaporation, e.g., solar collectors or external condensers. In contrast, passive solar still occurs when evaporation and condensation occur naturally, and solar is the sole energy source for the system (Aybar 2007;

35 Kalidasa Murugavel et al., 2013; Adio et al., 2021). United Nations (1970) and Talbert and Eibling (1970) have described other types of solar still and the operation theory related to solar still energy balance in their manuals.

Many researchers have explored methods to increase the productivity of solar still because of its low efficiency and productivity. This limitation has made solar still a less competitive water purification method for commercial applications (Jamil and Akhtar, 2017). Some of the attempted approaches include geometry optimization through design (Khalifa and

40 Hamood 2009; Khalifa 2010; Arunkumar et al., 2012; Ahsan et al., 2014; Feilizadeh et al., 2017; Jamil and Akhtar 2017), using energy absorbing material (Okeke et al., 1990; Ahmed and Ibrahim 2016; Nafey et al., 2001), and using additional components (Abdelkader 2006; Ayoub et al., 2013; Madhlopa 2009). These modifications are costly, require skilled labor and additional energy input. Consequently, these modified systems are unsuitable for remote areas and during emergencies (Ayoub et al., 2013; Ahsan et al., 2014). Although solar distillation has existed for many decades, solar still's performance and 45 productivity continue to be a relevant topic today.

It is recognized that the productivity of solar still is affected by many factors like location, sun position, design or type, and operational factors (Akash et al., 2000; Muftah et al., 2014). These factors are generally classified as either climatic, operational, or design (COD) parameters. Examples of climate factors that affect productivity are ambient temperature, solar radiation, weather conditions, and wind velocity. Operating factors often investigated are water depth, water salinity, still

50 orientation, and initial water temperature. Design factors include glass cover inclination, evaporation surface area, construction materials, and specific height. Researchers have examined the influence of climate parameters on solar still productivity, particularly solar radiation (Nafey et al., 2000; Tarawneh and Muafag 2007; Khalifa and Hamood 2009b; Ahsan et al., 2014; Muftah et al., 2014; Panchal and Patel 2016), wind speed (El-Sebaii 2000; Nafey et al., 2000; Muftah et al., 2014; Panchal and Patel 2016), ambient temperature (Ahsan et al., 2014; Muftah et al., 2014; Panchal and Patel 2016), dust deposition and cloud cover (Muftah et al., 2014). Similar and contradictory results have been reported depending on the study location.

In Nigeria, four climate types are present, depending on the region. Our experiment's location falls within the tropical savanna climate designated by the Köppen-Geiger climate system. The climate is marked by distinct rainy and dry seasons year-round (Leong, 1971); however, the dry season is hot and dry with harmattan wind. Harmattan is a dry dusty-laden atmosphere that occurs from November to March each year. This continental tropical air mass from the Sahara desert is transported by a northeasterly wind and has low humidity (Agada et al., 2011). The scattering of dust particles reduces solar radiation and covers transmissivity with dust accumulation (Egarievwe et al., 1991). Since solar still's output varies because of a timevariable energy source (United Nations 1970) and climate, the spatiotemporal elements are challenging to control. Hence, solar still's productivity characteristics are location-specific. 
There are few studies on the effect of harmattan on the productivity of solar still under a tropical savanna climate. Egarievwe

65 et al. (1991) presented harmattan performance analysis of a glass-covered concrete-basin solar still located at Nsukka $\left(6.80^{\circ} \mathrm{N}\right.$, $7.35^{\circ} \mathrm{E}$ ) in the African guinea savannah of southeast Nigeria. They used a cover tilt angle of approximately $31^{\circ}$ and lined the concrete basin with Polyvinyl Chloride (PVC). However, the optimal tilt angle of the cover close to the location's latitude is reported to be more appropriate (Khalifa 2010; Cherraye et al., 2020). In addition, steel basin has a better thermal conductivity that improves production capacity than concrete or PVC (Barve and Ithape, 2017). In another study, Babalola et al. (2015)

70 reported the performance of double slope solar still tilted at $50^{\circ}$ under normal tropical savanna climatic conditions in Lagos $\left(6.5^{\circ} \mathrm{N}, 3.35^{\circ} \mathrm{E}\right)$ with no focus on the harmattan effect. However, single-sloped south-facing still has received more radiation for low latitude locations (Garg and Mann, 1976). Many investigations on solar still performances have been conducted under various climatic conditions (Kamal 1988; Akash et al., 2000; Zeroual et al., 2011; Sarkar et al., 2017; Alwan et al., 2020). However, the performance of single basin solar still's during harmattan season in Ile Ife $\left(7.51^{\circ} \mathrm{N}, 4.52^{\circ} \mathrm{E}\right)$ southwest Nigeria

75 has not been reported in the literature.

Hence, this study aims to understand the variation of climate factors on solar still's productivity during harmattan, how selected COD parameters may affect productivity and purification efficacy. The study objectives are (a) to design and fabricate a single basin-type solar still, (b) to analyze the variation of climatic factors with productivity during the harmattan season, (c) to investigate simultaneously the individual and combined influences of water temperature, water salinity, water depth on performance via the design of experiment (DOE) (d) to determine impurities removal efficacy.

\section{Methodology}

\subsection{Experimental set-up for performance assessment}

This study was conducted at the Civil Engineering Department at Obafemi Awolowo University, Ile-Ife, Nigeria $\left(7.51^{\circ} \mathrm{N}\right.$, $\left.4.52^{\circ} \mathrm{E}\right)$ between October and December. Two basin-type solar stills, alpha $(\alpha)$ and beta $(\beta)$ were fabricated with a $2 \mathrm{~mm}$ thick galvanized iron sheet (Madhlopa 2009; Kopperdal 2015) and other locally sourced materials. The design parameters of the fabricated stills and relevant references that influenced the choice of these parameters are shown in Table 1. Purified water collecting trough (U-shaped) is made from polyvinyl chloride (PVC) pipe and attached just below the glass cover on the south wall, inside the solar still. The trough is sloped to enable the gravity flow of purified water via a connected hose into a distillate bottle. Figure 1 shows the experimental set-up and cross-sectional view of the solar stills. The solar stills were sealed with

90 silicone sealant to prevent vapor leakage as recommended by Nafey et al. (2000) after the transparent glass cover was fixed into position. Coal tar was applied to the lower portion of inside walls and the inner base of the solar stills to improve the solar absorptivity of the still basin, as recommended by Nafey et al. (2001).

Heat loss from the base is minimized by placing solar still on a wooden frame that provides $25 \mathrm{~mm}$ thick insulation, following Messel and Butler (1975) recommendations. Water temperature was measured by a digital microprocessor connected to a type-

$95 \mathrm{~K}$ thermocouple probe in contact with water in the solar still. 

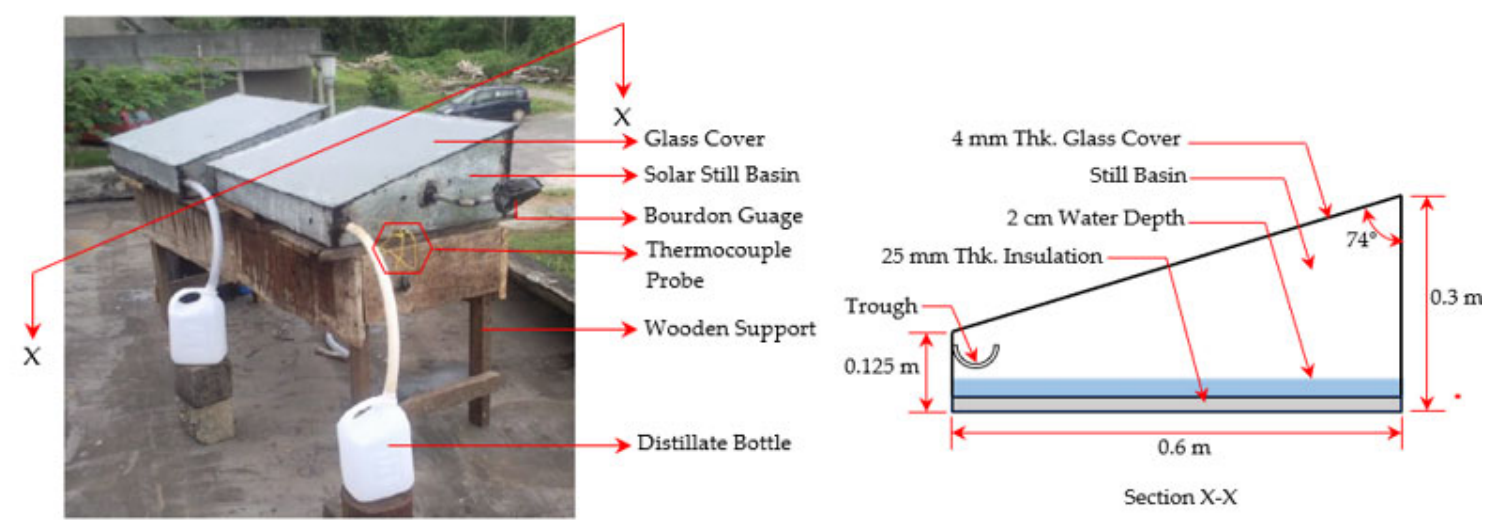

Figure 1: (a) Experimental set-up of single basin-type solar still (b) X-X sectional view of single basin-type solar still

Table 1: Design parameters of a single basin-type solar still

\begin{tabular}{llll}
\hline No. & Parameter & Value & References \\
\hline 1. & Length, $\mathrm{L}$ & $0.8 \mathrm{~m}$ & Madhlopa 2009 \\
2. & Width, W & $0.6 \mathrm{~m}$ & Madhlopa 2009 \\
3. & Front Wall Height, $\mathrm{H}_{\mathrm{F}}$ & $0.125 \mathrm{~m}$ & Madhlopa 2009; \\
4. & Back Wall Height, $\mathrm{H}_{\mathrm{B}}$ & $0.300 \mathrm{~m}$ & Madhlopa 2009; \\
5. & Aspect Ratio (L/W) & $1.33 \mathrm{~m}$ & Madhlopa 2009 \\
6. & Cover Tilt Angle, $\theta$ & $16^{\circ}$ & Tiwari et al. (1994); Qiu and Riffat (2003); Ali Samee et al. (2007) \\
7. & Cover glass thickness & $4 \mathrm{~mm}$ & Ghoneyem and Ileri (1997); Kabeel and El-Agouz (2011) \\
\hline
\end{tabular}

100

The glass cover temperature was estimated using semi-empirical equations proposed by Sharma and Mullick (1992), shown in Eq. (1) and Eq. (2). The equations were obtained from an approximate solution of the heat balance equations of a basin-type solar still with minor computational errors that closely match numerical solutions. In addition, a bourdon gauge was connected to the solar still $(\alpha)$ to measure vapor pressure. However, the bourdon gauge was insensitive to the vapor pressure developed

105 in the solar still, and vapor pressure measurement was discontinued for this study. The solar stills were positioned facing the south as recommended by Garg and Mann (1976).

$$
T_{g}=\frac{\left(0.02612 T_{w}^{2}-15.76 T_{w}+2392\right) T_{w}+A_{r} h_{w} T_{a}+A_{r}\left(0.048 T_{a}-9\right) T_{s}}{\left(0.02612 T_{w}^{2}-15.76 T_{w}+2392\right)+A_{r} h_{w}+A_{r}\left(0.048 T_{a}-9\right)}
$$

$$
T_{s}=0.0552 * T_{a}^{1.5}
$$

Where $T_{g}, T_{w}, T_{a}$ are glass, water, and ambient temperature, $A_{r}$ is the ratio of glass area to the water area and, $h_{w}$ is the wind heat transfer coefficient. Water samples collected from the stream behind the Civil Engineering Building at Obafemi Awolowo University, Ile-Ife, Nigeria was used for this experimental investigation. The stream water was added into the solar stills via 
an inlet port on the north wall up to $2 \mathrm{~cm}$ depth based on Talbert and Eibling (1970) and Tarawneh and Muafag (2007)

115 recommendations at the beginning of each day. Tri-horal distillate volume from the solar still was collected, measured using a graduated cylinder, and recorded between 9:00 and 18:00 local time throughout the experiment. Table 2 shows the list of laboratory and field equipment used for the experimental study.

Climatic data for Ile-Ife $\left(7.51^{\circ} \mathrm{N}, 4.52^{\circ} \mathrm{E}\right)$, precisely the ambient temperature, relative humidity, wind speed, rainfall, and solar irradiation, was obtained from the SoDa web service. SoDa provides historical, real-time, and forecast weather data services derived from Meteosat geostationary satellites images.

Table 2: Instruments' specification

\begin{tabular}{lllll}
\hline No. & Instrument & Accuracy & Range & Error \\
\hline 1. & K-Type Thermocouple Thermometer & $0.1^{\circ} \mathrm{C}$ & -0 to $100{ }^{\circ} \mathrm{C}$ & $\pm 0.1^{\circ} \mathrm{C}$ \\
2. & Pyrex Graduated Cylinder, Class B & $1 \mathrm{~mL}$ & 0 to $200 \mathrm{~mL}$ & $\pm 0.1 \mathrm{~mL}$ \\
3. & Weighing balance; Mettler Toledo - PB153 & $0.001 \mathrm{~g}$ & 0 to $151 \mathrm{~g}$ & $\pm 0.002 \mathrm{~g}$ \\
4. & pH meter; Extech Instruments - Model 407227 & $0.1 \mathrm{pH}$ & 0 to $14 \mathrm{pH}$ & $\pm 0.03 \mathrm{pH}+2$ digits \\
\hline
\end{tabular}

\subsection{Effects of selected COD parameters on productivity}

125 The simultaneous individual and combined influences of three selected factors on the performance of solar still during harmattan were investigated by $2^{3}$ factorial design experiments. The selected factors are water temperature, water depth, and salinity. These factors were tested at two levels reflecting likely operating levels for each factor. Eight experiments were performed corresponding to $2^{\mathrm{k}}$ factorial design, where $\mathrm{k}$ represents the number of factors investigated, and two (2) refers to the number of levels per factor. With three factors each taking two levels, this makes up a 2 x 3 factorial experiment design. Table

1303 shows the levels of the factors studied represented by coded units $( \pm)$ for computational purposes in the standard order table. The real-world units used for water depth are $2 \mathrm{~cm}$ and $4 \mathrm{~cm}$. For salinity, $500 \mathrm{ppm}$ and $2500 \mathrm{ppm}$ salt concentrations represent low and high levels, respectively. The water salinity was accomplished by dissolving kitchen salt in the feedwater before pouring it into the solar stills (Akash et al., 2000).

The water temperature levels were implicitly selected according to the time of day. Water temperature at noon was recorded

135 as low level. In contrast, water temperature at 15:00 local time was recorded as high because it is expected that water temperature would increase with time, assuming a sunny day. Water depth was varied the fastest, followed by salinity, and water temperature varied the slowest. The experiment was run randomly according to the actual order column in Table 3.

\subsection{Water impurities removal efficiency}

As part of the study objectives, laboratory tests were performed to determine water quality parameters of total solids (TS),

140 suspended solids (SS), and dissolved solids (DS) concentrations by the gravimetric method. The $\mathrm{pH}$ of the distilled water was determined by a $\mathrm{pH}$ meter (Table 2) at room temperature. These tests were performed before and after adding the sample 
stream water into the solar still. Hanson et al. (2004) and Zarasvand Asadi et al. (2013) have reported the efficiency of solar still in removing bacteria, organic and inorganic compounds, and in treating wastewater. No bacteriological, hardness, or organic compound tests were performed for this study. Two water quality tests were performed in November and December.

145 An additional test, particularly the total solid (TS) test, was repeated after noticeable changes in stream turbidity during sampling to confirm our visual observations.

\subsection{Data analysis}

Before data analysis, the dataset was checked for completeness and curated in Microsoft Excel. The data were then processed and visualized using Microsoft Excel spreadsheets. A paired t-test was conducted to test a hypothesis for the equality of mean

150 of the measured distillate from solar stills $\alpha$ and $\beta$. Variation of climate factors and productivity with daytime plots were generated for inferential analysis. In addition, a $2^{3}$ factorial DOE calculation was completed to gauge main and interaction influences of water depth, water temperature, and salinity. DOE is a statistical technique used to study the effect of multiple variables simultaneously. It is suitable for problems whose solution is a combination of factors rather than single identifiable causes (Al-Smadi et al., 2012). TS, SS, DS, and pH of the distilled water samples were compared to World Health Organization

155 (WHO) drinking water standards to estimate the efficiency of the solar still in removing the tested water impurities.

\section{Results and discussion}

\subsection{Hypothesis Testing of Equality of Volume of Distillate Mean}

A paired t-test was conducted to compare measured distillate from solar stills $\alpha$ and $\beta$ by hypothesis testing for mean equality. The test was performed to ensure fabrication assurance and ascertain that the solar still device functioned as designed. The

160 computed test statistic ts (1.037) was compared to the reference distributions tr (2.988) at $1 \%$ significant level and tr (1.895) at $5 \%$ significant level. The alternative hypothesis was rejected, indicating no significant difference between the volume of distillate obtained from solar stills $\alpha$ and $\beta$. The rejected hypothesis suggests the absence of influence of other external factors.

\subsection{Preliminary climate factors and productivity data characterization}

Initially, scatter plots and Pearson's correlation coefficient matrix were generated to identify any underlying correlation structure or relationship between the variables in Fig. 2. Generally, the plot revealed a range of interrelationships with no unique structure. The correlation coefficients indicated the degree of linear relationship amongst the factors without implying any cause-and-effect. A high coefficient close to \pm 1 implies a robust linear relationship between the variables. In contrast, a low coefficient implies a weak linear or nonlinear relationship ("NIST/SEMATECH e-Handbook of Statistical Methods" 2012). The cells not on the diagonals represent the interrelatedness of factors presented as either a scatter plot or correlation

170 coefficient. Ambient temperature, relative humidity, and rainfall appeared to have the most significant influences on productivity and were examined further. 


\begin{tabular}{|c|c|c|c|c|c|}
\hline $\begin{array}{c}\text { Daily Average } \\
\text { Solar } \\
\text { Irradiation } \\
\left(\mathrm{Wh} / \mathrm{m}^{2}\right)\end{array}$ & -0.1695 & -0.5287 & -0.0474 & -0.2946 & 0.1248 \\
\hline $\begin{array}{l}\therefore \\
\therefore\end{array}$ & $\begin{array}{l}\text { Daily Average } \\
\text { Ambient } \\
\text { Temperature } \\
\text { (C) }\end{array}$ & 0.8302 & -0.5629 & 0.6091 & 0.4035 \\
\hline $\begin{array}{c}\cdot \\
. \\
. \\
.\end{array}$ & & $\begin{array}{l}\text { Daily Average } \\
\text { Relative } \\
\text { Humidity (\%) }\end{array}$ & -0.2725 & 0.7591 & 0.4308 \\
\hline 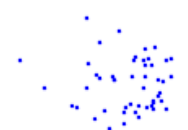 & & $\begin{array}{l}\because \\
\because \\
\because \vdots\end{array}$ & $\begin{array}{l}\text { Daily Average } \\
\text { Wind Speed } \\
(\mathrm{m} / \mathrm{s})\end{array}$ & 0.0107 & 0.001 \\
\hline $\begin{array}{c}\cdot \\
\ddots \\
\ddots \\
\because \cdots \\
\because \cdots\end{array}$ & $\begin{array}{r}\vdots \\
\because \\
\therefore \\
\therefore\end{array}$ & $\begin{array}{c}\therefore \\
\therefore \\
\therefore\end{array}$ & $\begin{array}{c}\vdots \\
\vdots \vdots \\
\vdots \cdots\end{array}$ & $\begin{array}{c}\text { Daily } \\
\text { Average } \\
\text { Rainfall (mm) }\end{array}$ & 0.5008 \\
\hline$\cdot . \therefore \%$ & 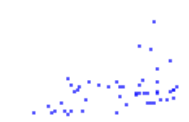 & 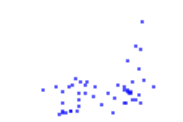 & 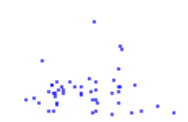 & ${ }^{\cdot} \cdot{ }^{\cdot} \cdot$ & $\begin{array}{c}\text { Daytime } \\
\text { Productivity } \\
\left(\mathrm{m} 1 \mathrm{~m}^{-2} \text {.day) }\right.\end{array}$ \\
\hline
\end{tabular}

Figure 2: Scatter plot and Pearson's correlation coefficient matrix for comparisons among climate factors and productivity. The

upper diagonal shows Pearson's correlation coefficients, and the lower diagonal the scatter plots

\subsection{Variation of solar irradiation and productivity with daytime}

According to Pillai et al. (2015), the primary energy source and single-most factor dictating solar still productivity is solar radiation. However, a correlation coefficient of irradiation and productivity of 0.1248 revealed little or no linear relationship between them in Fig. 2. This observation is physically irrational, and a deeper examination is essential. Typical tri-horal variation of solar irradiation and productivity for randomly selected days is shown in Fig. 3. It was observed that solar radiation reaches maximum value around noon. A similar trend was observed for productivity; however, productivity reaches its maximum at around 15:00 local time. There is a 3-hour time lag between irradiation and productivity; this lag in productivity may be attributed to increased thermal inertia ${ }^{1}$ due to higher internal temperature. Ahsan et al. (2014) observed a similar time

\footnotetext{
${ }^{1}$ Thermal inertia is the property of a material that expresses its capacity to store heat and delay transmission
} 
185 lag in their experiment in Malaysia. The average tri-horal irradiation was $443.8 \mathrm{Wh} / \mathrm{m}^{2}$ and range between $5.5 \mathrm{Wh} / \mathrm{m}^{2}$ to 938.8 $\mathrm{Wh} / \mathrm{m}^{2}$. The maximum irradiation occurred on day December 2 at noon. The average daily productivity range between 29.7 $\mathrm{ml} \mathrm{m} \mathrm{m}^{-2} \cdot$ day $^{-1}$ and $146.9 \mathrm{ml} \cdot \mathrm{m}^{-2} \cdot$ day $^{-1}$.
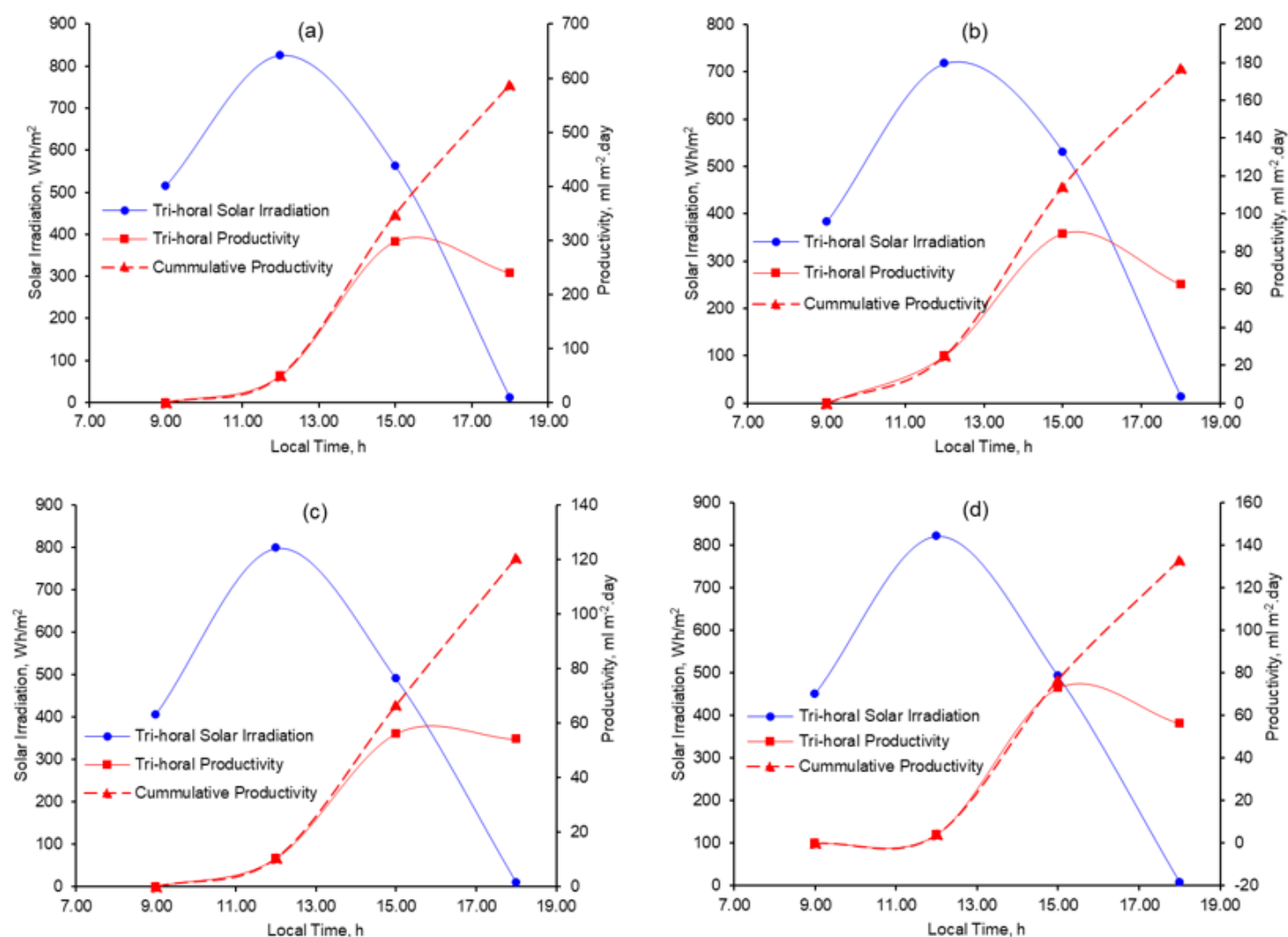

Figure 3: Variation of solar radiation and productivity with daytime (a) Day 1 (b) Day 9 (c) Day 42 and (d) Day 48

\subsection{Variation of ambient, Water, and glass temperature, and productivity with daytime}

Typical daily variation of temperatures and productivity with daytime is presented in Fig. 4(a)-(d) for four randomly selected days of the duration of the experiment. Water temperature was observed to be higher than the ambient temperature and the estimated glass temperature. The average water temperature was $42.1^{\circ} \mathrm{C}$ and range between $14.9^{\circ} \mathrm{C}$ and $63.6^{\circ} \mathrm{C}$. Overall, the highest water temperature occurred in November, and the lowest water temperature was recorded in December. The average ambient temperature was $26.7^{\circ} \mathrm{C}$ for the duration of the experiment and ranges between $19.1{ }^{\circ} \mathrm{C}$ and $30.2^{\circ} \mathrm{C}$. The highest 
ambient temperature was typically recorded between noon and 15:00 local time. On some days, the highest instantaneous productivity was recorded around 15:00 local time like Fig. 4 (a) and (d). However, it was recorded at 18:00 local time like Fig. 4 (b) and (c) for other days. The inconsistency may explain the low correlation between productivity and ambient 200 temperature in Fig. 2.
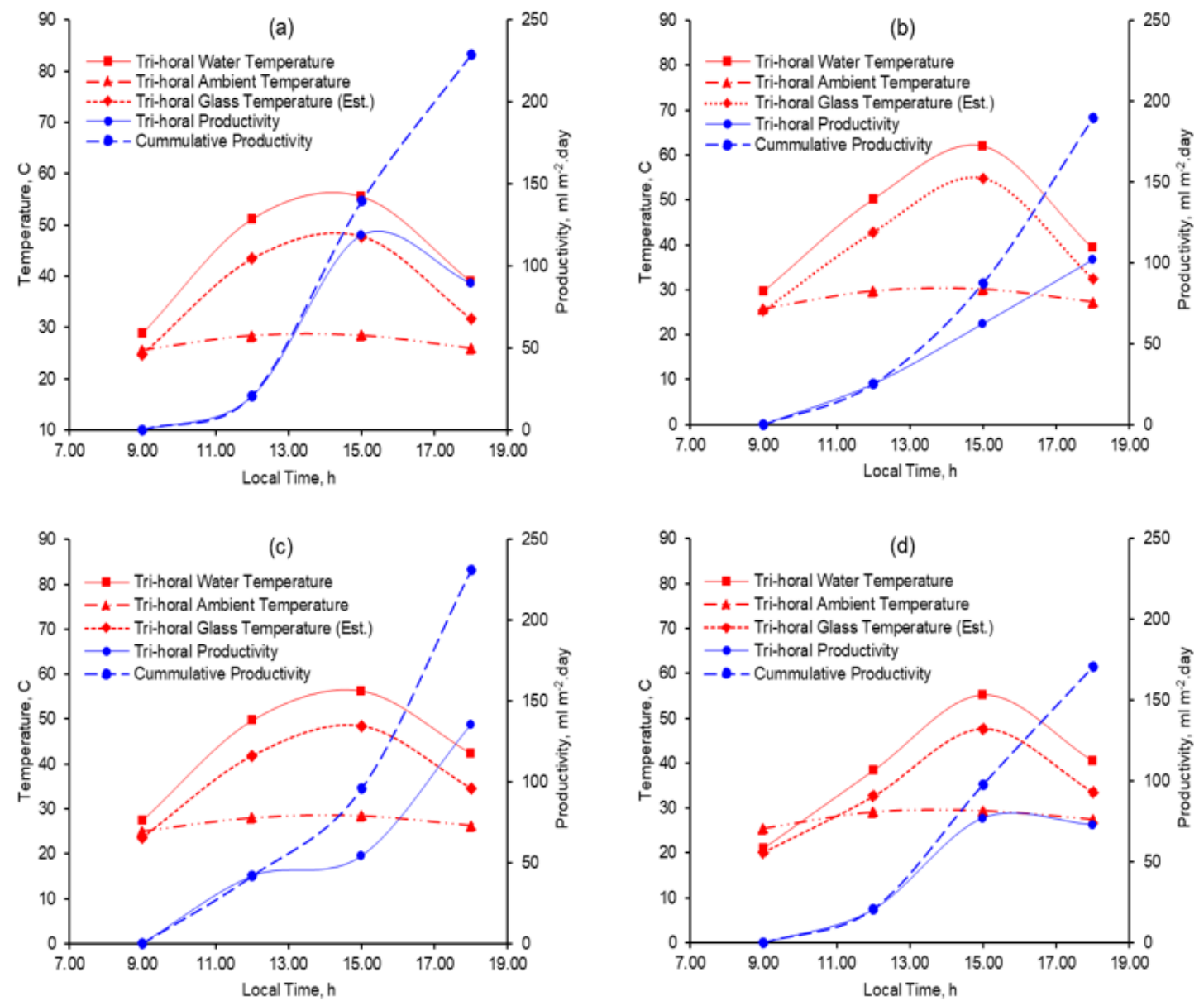

Figure 4: Variation of ambient, water, and glass temperature, and productivity with daytime (a) Day 8 (b) Day 10 (c) Day 14 and (d) Day 46

\subsection{Variation of relative humidity and productivity}

205 In Nigeria, the climate is characterized by generally low humidity during the harmattan months (Onyegegbu, 1989). The minimum and maximum tri-horal relative humidity recorded for the experiment was $39 \%$ and $91 \%$, respectively. This relative 
humidity range of $52 \%$ is well above expected and atypical of the harmattan season. For a typical daily variation, the humidity was highest at the beginning and end of the day and lowest between 13:00 and 15:00 local time. The maximum and minimum average daily daytime productivity corresponds to about $86 \%$ and $59 \%$ relative humidity. From Fig. 5, low relative humidity does not appear to translate to higher productivity. In general, the average relative humidity was higher in November than in December. Correspondingly, the average daily productivity of $65.7 \mathrm{ml} \mathrm{m}^{-2}$.day for November was higher than $47.8 \mathrm{ml} \mathrm{m}^{-2}$.day for December. However, the correlation coefficient of Fig. 2 does not show a strong linear relationship.

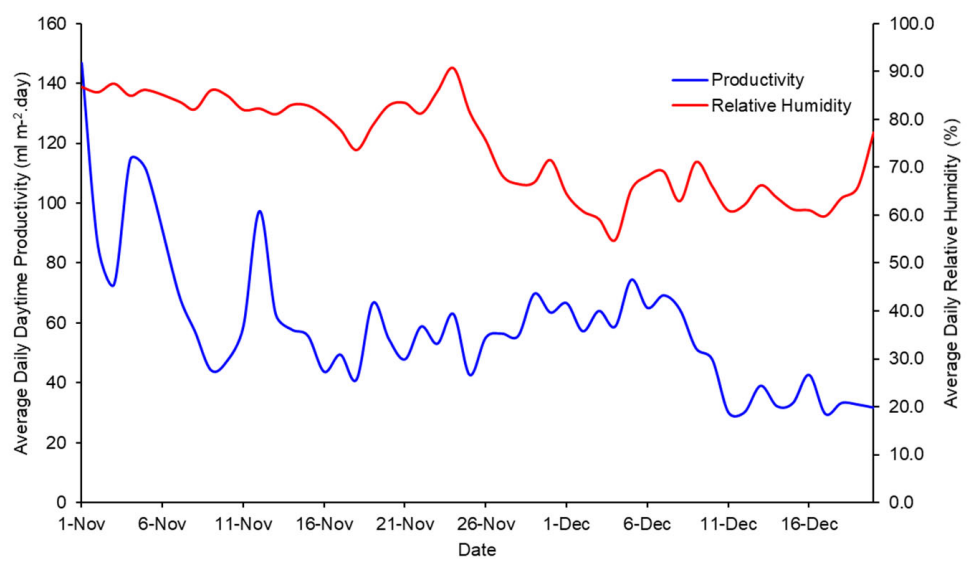

Figure 5: Average daily variation of relative humidity and productivity.

\subsection{Variation of rainfall and productivity}

The temperature gradient between water and glass cover is an essential factor affecting the productivity of solar still, with a higher gradient resulting in higher productivity (Sadineni et al., 2006). Some researchers have investigated the use of water sprinklers to achieve lower glass temperature (Tarawneh and Muafag, 2007) or intermittent cold water pouring over the glass cover (Elashmawy, 2019). Rainfall may have a similar temperature lowering effect on the glass cover of solar still. The amount of rainfall recorded for the duration of the experiment range from $0 \mathrm{~mm}$ to $0.4 \mathrm{~mm}$, while the average daily tri-horal rainfall was $0.036 \mathrm{~mm}$. From Fig. 6, it was observed that November experienced more rainfall than December, which saw little to no rainfall. Higher average daily productivity of $65.7 \mathrm{ml} \mathrm{m}^{-2}$.day for November compared to $47.8 \mathrm{ml} \mathrm{m}^{-2}$.day for December suggests that rainfall may positively increase productivity by lowering the glass temperature. A similar observation was reported by Egarievwe et al. (1991). 


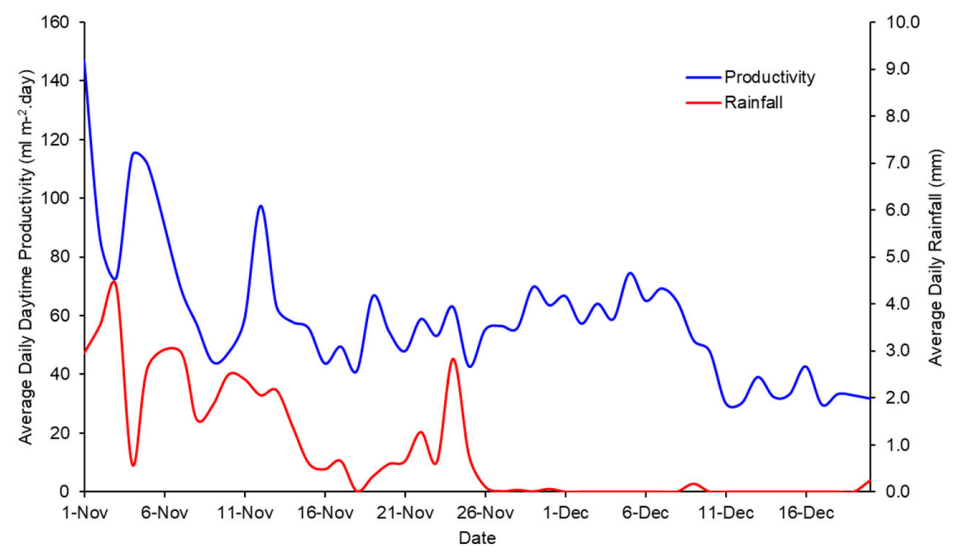

Figure 6: Average daily variation of rainfall and productivity

\subsection{Variation of wind speed and productivity}

230 Convective heat transfer coefficient from glass cover to ambient is dependent on wind velocity (Morse and Read 1968; Charles et al., 2010). However, the correlation between wind speed and productivity is very low, as shown in Fig. 2 from the experimental data. This low correlation is corroborated by the United Nations (1970), which stated that the effect of wind is unimportant on the output of the still. They, however, noted that sudden changes in wind velocity would cause momentary changes in output that balance out over a period. On the contrary, using numerical simulation, El-Sebaii (2000) found that

235 productivity increases with wind speed up to a typical velocity between $8 \mathrm{~m} / \mathrm{s}$ to $10 \mathrm{~m} / \mathrm{s}$ for summer and winter days, respectively. Beyond these velocities, any increase in productivity becomes insignificant. Tri-horal wind speeds for the experiment were of the order of $0.1 \mathrm{~m} / \mathrm{s}$ to $3.7 \mathrm{~m} / \mathrm{s}$. Figure 7 also indicated that low average daily wind speed sometimes corresponds to moderate to high productivity. This observation is supported by El-Sebaii (2000). 


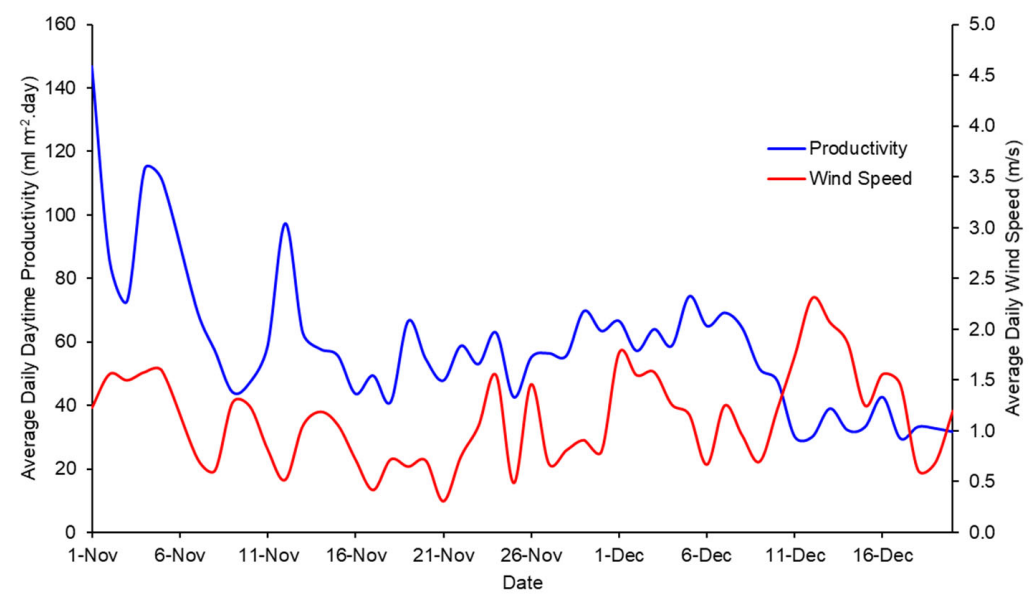

Figure 7: Average daily variation of wind speed and productivity

\subsection{Design of Experiment (DOE)}

The effect of selected COD parameters on productivity was estimated using the Yates algorithm in a 2-level factorial design. The Yates algorithm exploits the unique structure of these designs to generate least squares estimates for factor effects for all

245 factors and all relevant interactions (Anon, 2012). The goal of the experimental design is to determine the critical factors that affect productivity and the combination that maximize productivity. Table 3 shows the order table and measurement from the experiment.

Table 3: Order table and measurement results for 23 factorial design experiments

\begin{tabular}{|c|c|c|c|c|c|c|c|c|c|}
\hline \multirow{2}{*}{$\begin{array}{l}\text { Average } \\
\text { Distillate }\end{array}$} & \multicolumn{3}{|c|}{ Factors } & \multirow{2}{*}{$\begin{array}{l}\text { Exp. } \\
\text { Order }\end{array}$} & \multirow[t]{2}{*}{ Effect } & \multirow[t]{2}{*}{$\mathrm{C1}$} & \multirow[t]{2}{*}{$\mathrm{C2}$} & \multirow[t]{2}{*}{ C3 } & \multirow[t]{2}{*}{ Estimate } \\
\hline & $\mathbf{X 1} \mathbf{1}^{\#}$ & $\mathbf{X 2 ^ { \# }}$ & $\mathbf{X 3}^{\#}$ & & & & & & \\
\hline 29.0 & - & - & - & 6 & Mean & 34.5 & 50 & 267 & 33.375 \\
\hline 5.5 & + & - & - & 7 & $\mathrm{X} 1$ & 15.5 & 217 & -92 & -11.5 \\
\hline 10.5 & - & + & - & 1 & $\mathrm{X} 2$ & 151.5 & -29 & -105 & -13.125 \\
\hline 5.0 & + & + & - & 4 & $\mathrm{X} 1 * \mathrm{X} 2$ & 65.5 & -63 & 30 & 3.75 \\
\hline 94.5 & - & - & + & 5 & $\mathrm{X} 3$ & -23.5 & -19 & 167 & 20.875 \\
\hline 57.0 & + & - & + & 2 & $\mathrm{X} 1 * \mathrm{X} 3$ & -5.5 & -86 & -34 & -4.25 \\
\hline 45.5 & - & + & + & 3 & $\mathrm{X} 2 * \mathrm{X} 3$ & -37.5 & 18 & -67 & -8.375 \\
\hline 20.0 & + & + & + & 8 & $\mathrm{X} 1 * \mathrm{X} 2 * \mathrm{X} 3$ & -25.5 & 12 & -6 & -0.75 \\
\hline
\end{tabular}




\subsubsection{Main effect on productivity}

The ordered plot for the experimental data was generated as a first step to detect the most significant factor, as shown in Fig. 8(a). Three out of four highest distillate volume values recorded have $\mathrm{X} 3=+$, while three out of four lowest response values recorded have X3 = -. It suggests that factor X3 (water temperature) is the most significant factor. The main effect is more clearly depicted by the DOE mean plot, as shown in Fig. 8(b). The eyeball distance between the mean values in the mean plot approximates the least-squares estimate of the factor effects. The water temperature effect is clearly shown to be large and the most significant. The order of importance of the main effect is water temperature, water salinity, and water depth. High salinity and water depth tend to decrease productivity; in contrast, the water temperature increases productivity from low to high levels. The effect of water salinity on productivity is slightly higher than water depth, as shown in Fig. 8(b), based on the distance between the mean.
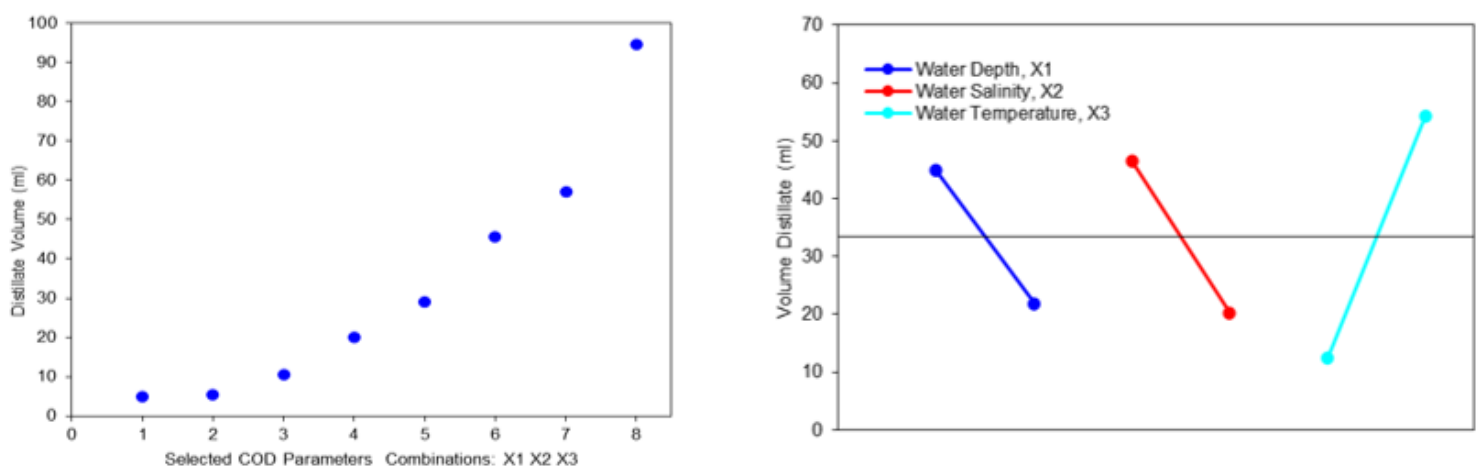

Figure 8: (a) Ordered distillate volume data plot and (b) DOE mean plot

\subsubsection{Interaction effect on productivity}

265 For a $k$-factor experiment, the effect on the response could be due to central effects and various interactions up to $k$-term interactions (Anon, 2012). The interaction effects plot shown in Fig. 9 summarizes the changes in productivity from low to high levels of the factors, i.e., water depth, water salinity, and water temperature. The order of importance of the 2-factor interaction effects is water salinity-water temperature, water depth-water temperature, and water depth-water salinity effect. Only water depth-water salinity has a positive effect on productivity. In simple terms, larger water volume nullifies salinity by dilution at low levels. The effect of the 3-factor interaction is negligible, as shown in Fig. 9. The line showing this effect is nearly parallel to the mean line, indicating a negligible effect. 
https://doi.org/10.5194/dwes-2021-19

Preprint. Discussion started: 14 January 2022

(c) Author(s) 2022. CC BY 4.0 License.

\subsubsection{Estimation of main and interaction effects on productivity}

The change in productivity per one unit of the factor variable was estimated using the least-square regression by analyzing the data from the factorial design. The full model for the $2^{3}$ factorial design is given by Eq. (4). The regression coefficients represent the factor variable's unit change. The effect estimates from the analysis for the full model are shown in Table 3.

$$
Y=\mu+\beta_{1} X_{1}+\beta_{2} X_{2}+\beta_{3} X_{3}+\beta_{12} X_{1} X_{2}+\beta_{13} X_{1} X_{3}+\beta_{23} X_{2} X_{3}+\beta_{123} X_{1} X_{2} X_{3}+\epsilon
$$

Where $\epsilon$ is a residual error, $X_{i}$ are the factor variables, and $\beta_{i}$ are the regression coefficients for the model. Following a ranking, the most significant to lowest factors are water temperature, water salinity, depth, and salinity-water temperature interaction. Fig. 9 shows the interaction plots for comparison.
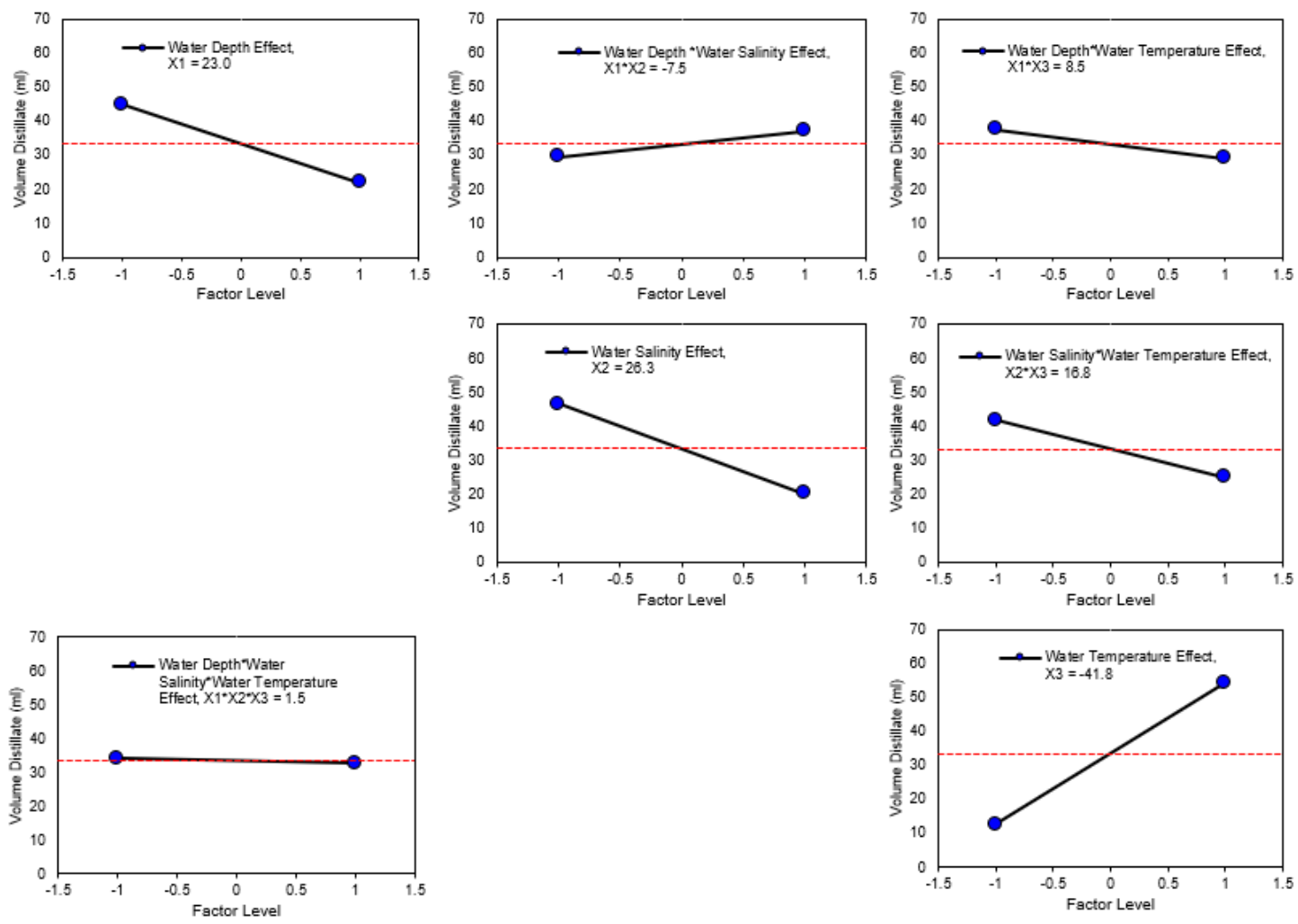

Figure 9: DOE interaction plots for solar still productivity data 


\subsubsection{Water impurities removal efficiency}

In Table 4, tested water impurity parameters of feedwater and distillate used to evaluate the efficacy of the solar still to remove such impurity is presented. A $10 \%$ reduction in $\mathrm{pH}$ of the feedwater was observed after distillation. $\mathrm{pH}$ measurement is on a standard scale of 0 to 14 that designates the acidity of water. The solids concentrations are an indicator of the overall quality of the water. The values of these parameters were compared to the World Health Organization (2011) standards guidelines for drinking water quality and used as a baseline for water purification efficiency in Table 4.

Table 4: Summary of test results

\begin{tabular}{lllll}
\hline Parameters & Feedwater & Distillate & Efficiency (\%) & $\begin{array}{l}\text { WHO } \\
\text { Standards }\end{array}$ \\
\hline TS $(\mathrm{mg} / \mathrm{L})$ & 2900 & 513.3 & 82.3 & - \\
$\mathrm{SS}(\mathrm{mg} / \mathrm{L})$ & 246.7 & 46.7 & 81.1 & - \\
$\mathrm{DS}(\mathrm{mg} / \mathrm{L})$ & 2653.3 & 466.6 & 82.4 & $<600$ \\
$\mathrm{pH}$ & 7.285 & 6.520 & - & $6.5-8.5$ \\
Temperature $\left({ }^{\circ} \mathrm{C}\right)$ & 25.5 & 25 & - & - \\
\hline
\end{tabular}

\section{Conclusion}

295 This study investigated the performance of a basin-type solar still during the harmattan season under the prevailing tropical savanna climate conditions of Ile Ife in southwest Nigeria. The variation of solar irradiation, ambient temperature, wind speed, rainfall, and relative humidity with the productivity of the solar still during the day was analyzed. The study was extended to estimate the effect of water depth, salinity, and water temperature on productivity via the DOE technique. Finally, the purification efficiency of the solar still in terms of solid concentrations and $\mathrm{pH}$ was ascertained. Uncertainties in engineering systems are due to ambiguities in variable definition and their relationship, originating from physical randomness, limited data for variable characterization, and fabrication quality. Some of these uncertainty issues were addressed in this study.

Results revealed that even though solar irradiation is the sole energy input to solar stills', its correlation with productivity was low. Lag in peak productivity and peak irradiation was observed; this perhaps is the effect of thermal inertia and explains the low correlation between irradiation and productivity. A similar lag existed between irradiation and water temperature. Water

305 temperature was higher than the ambient temperature for the experiment indicating the solar still absorber plate is performing as designed. Although, in some instances, high water temperature corresponds to high productivity; however, this is not always the case for the experiment. We concluded that irradiation is not solely responsible for productivity and other factors contribute or limit it. For relative humidity, the maximum and minimum average daily productivity corresponds to $86 \%$ and $59 \%$ relative humidity. In December, the average relative humidity decreased by $10 \%$ from November, and a corresponding decrease in

310 productivity was observed. However, low relative humidity that usually characterizes the harmattan season does not appear to increase productivity. Lower rainfall occurred in December that resulted in a $31.2 \%$ decrease in average daily productivity from November, which suggests that rainfall may positively increase productivity by lowering the glass temperature. Low 
average daily wind speed sometimes corresponds to moderate or high productivity. Other investigators have reported similar observations supporting this conclusion. The effect of wind speed on productivity was not clearly shown from the experimental

315 data. Wind effect may be further investigated in future work, given that the maximum recorded wind speed was $3.7 \mathrm{~m} / \mathrm{s}$. The attempt to measure the vapor pressure in the solar still was aborted due to the Bordon gauge's insensitivity; a digital pressure meter is proposed for such measurement.

In addition, the results of the factorial design experiment analysis revealed the water temperature effect to be the most significant. The order of importance of the main effects is water temperature, water salinity, and water depth. High salinity

320 and water depth tend to decrease productivity. The effect of water salinity on productivity is slightly higher than the water depth. The order of importance of the 2-factor interaction effects is salinity-water temperature, water depth-water temperature, and water depth-water salinity effect. Only the water depth-water salinity interaction effect increases productivity. In general, water temperature, salinity, depth, and s-t interaction (salinity and water temperature) are the most significant based on ranked order. Finally, the distillate qualities were within the acceptable limits for drinking water specified by the World Health

325 Organization standards guidelines for drinking water quality.

Data availability. Experimental data collected and secondary data sourced have been used to develop charts and tables in the article's main body. These data are accessible at https://data.mendeley.com/datasets/xhtnypxx6b/1(Ogunseye et al., 2021)

Author contribution. OO co-conceived the idea, led the experimental set-up and data collection, and wrote the paper. KO coconceived the idea, defined the problem, supervised the project, reviewed the data, and assisted with result interpretation.

330 Competing interest. The authors declare they have no conflict of interest

Acknowledgments. The authors wish to thank Mr. Ade Omole-Adebomi and Mr. Sulaimon Salami for their assistance in collecting design and operational data. The authors are immensely thankful to Dr. Claire Thomas of SoDa, for her expert opinions on sourcing the secondary data for this research work.

\section{References}

335 Abdelkader, M.: Design and Testing of a Solar Still Coupled With a Solar Centeral Receiver, in The 2nd International Conf. on Water Resources \& Arid Environment, pp. 1-26., 2006.

Adio, S. A., Osowade, E. A., Muritala, A. O., Fadairo, A. A., Oladepo, K. T., Obayopo, S. O. and Fase, P. O.: Solar distillation of impure water from four different water sources under the southwestern Nigerian climate, Drink. Water Eng. Sci., 14(1), 81-94, doi:10.5194/dwes-14-81-2021, 2021.

340 Agada, L. E., Malgwi, D. I. and Abbas, B. K.: Harmattan Dust and Its Effect in Semi-Arid Zone of Nigeria , A Case Study of 
Maiduguri Metropolis and Its Environs, , 6(1), 19-25, 2011.

Ahmed, H. M. and Ibrahim, G. A.: Performance Evaluation of a Conventional Solar Still with Different Types and layouts of Wick Materials, J. Energy Technol. Policy, 6(9), 5-14, 2016.

Ahsan, A., Imteaz, M., Thomas, U. A., Azmi, M., Rahman, A. and Nik Daud, N. N.: Parameters affecting the performance of a low cost solar still, Appl. Energy, 114, 924-930, doi:10.1016/j.apenergy.2013.08.066, 2014.

Akash, B. A., Mohsen, M. S. and Nayfeh, W.: Experimental study of the basin type solar still under local climate conditions, Energy Convers. Manag., 41(9), 883-890, doi:10.1016/S0196-8904(99)00158-2, 2000.

Al-Smadi, Y. M., Bhargava, A., Avci, O. and Elmorsi, M.: Design of experiments study to obtain a robust 3D computational bridge model, Conf. Proc. Soc. Exp. Mech. Ser., 1, 287-297, doi:10.1007/978-1-4614-2413-0_29, 2012.

350 Ali Samee, M., Mirza, U. K., Majeed, T. and Ahmad, N.: Design and performance of a simple single basin solar still, Renew. Sustain. Energy Rev., 11(3), 543-549, doi:10.1016/j.rser.2005.03.003, 2007.

Alwan, N. T., Shcheklein, S. E. and Ali, O. M.: Productivity of enhanced solar still under various environmental conditions in Yekaterinburg city / Russia, IOP Conf. Ser. Mater. Sci. Eng., 791(1), doi:10.1088/1757-899X/791/1/012052, 2020.

Anon: NIST/SEMATECH e-Handbook of Statistical Methods, , doi:https://doi.org/10.18434/M32189, 2012.

355 Arunkumar, T., Vinothkumar, K., Ahsan, A., Jayaprakash, R. and Kumar, S.: Experimental Study on Various Solar Still Designs, ISRN Renew. Energy, 2012, 1-10, doi:10.5402/2012/569381, 2012.

Aybar, H. S.: A review of desalination by solar still, NATO Secur. through Sci. Ser. C Environ. Secur., 207-214, doi:10.1007/978-1-4020-5508-9 15, 2007.

Ayoub, G. M., Malaeb, L. and Saikaly, P. E.: Critical variables in the performance of a productivity-enhanced solar still, Sol. Energy, 98(PC), 472-484, doi:10.1016/j.solener.2013.09.030, 2013.

Babalola, T., Boyo, A. and Kesinro, R.: Effect of Water Depth and Temperature on the Productivity of a Double Slope Solar Still, AJournal Energy Nat. Resour., 4(1), 1, doi:10.11648/j.jenr.20150401.11, 2015.

Barve, S. B. and Ithape, P. K.: Climatic and Design Parameters Effects on the Productivity of Solar Stills: A Review, Int. J. Curr. Eng. Sci. Res., doi:DOI:10.21276/ijcesr, 2017.

365 Boretti, A. and Rosa, L.: Reassessing the projections of the World Water Development Report, npj Clean Water, 2(1), doi:10.1038/s41545-019-0039-9, 2019.

Cherraye, R., Bouchekima, B., Bechki, D., Bouguettaia, H. and Khechekhouche, A.: The effect of tilt angle on solar still productivity at different seasons in arid conditions (south Algeria), Int. J. Ambient Energy, 0(0), 1-7, doi:10.1080/01430750.2020.1723689, 2020.

370 Egarievwe, S. U., Animalu, A. O. E. and Okeke, C. E.: Harmattan Performance of a solar still in the Guinea Savannah, Renew. Energy, 1(5/6), 799-801, 1991.

El-Sebaii, A. A.: Effect of wind speed on some designs of solar stills, Energy Convers. Manag., 41(6), 523-538, doi:10.1016/S0196-8904(99)00119-3, 2000.

Elashmawy, M.: Effect of surface cooling and tube thickness on the performance of a high temperature standalone tubular solar still, Appl. Therm. Eng., 156(December 2018), 276-286, doi:10.1016/j.applthermaleng.2019.04.068, 2019.

Garg, H. P. and Mann, H. S.: Effect of climatic, operational and design parameters on the year round performance of singlesloped and double-sloped solar still under Indian arid zone conditions, Sol. Energy, 18(2), 159-164, 1976.

Ghoneyem, A. and Ileri, A.: Software to analyze solar stills and an experimental study on the effects of the cover, Desalination, 114(1), 37-44, doi:10.1016/S0011-9164(97)00152-5, 1997.

380 Hanson, A., Zachritz, W., Stevens, K., Mimbela, L., Polka, R. and Cisneros, L.: Distillate water quality of a single-basin solar still: Laboratory and field studies, Sol. Energy, 76(5), 635-645, doi:10.1016/j.solener.2003.11.010, 2004.

Jamil, B. and Akhtar, N.: Effect of specific height on the performance of a single slope solar still: An experimental study, Desalination, 414, 73-88, doi:10.1016/j.desal.2017.03.036, 2017.

385 doi:10.1016/j.desal.2011.03.042, 2011

Kalidasa Murugavel, K., Anburaj, P., Samuel Hanson, R. and Elango, T.: Progresses in inclined type solar stills, Renew. Sustain. Energy Rev., 20, 364-377, doi:10.1016/j.rser.2012.10.047, 2013.

Kamal, W. A.: A theoretical and experimental study of the basin-type solar still under the arabian gulf climatic conditions, Sol. Wind Technol., 5(2), 147-157, doi:10.1016/0741-983X(88)90074-4, 1988.

390 Khalifa, A. J. N.: On the effect of cover tilt angle of the simple solar still on its productivity in different seasons and 
latitudes, Energy Convers. Manag., 52(1), 431-436, doi:10.1016/j.enconman.2010.07.018, 2010.

Khalifa, A. J. N. and Hamood, A. M.: Effect of insulation thickness on the productivity of basin type solar stills: An experimental verification under local climate, Energy Convers. Manag., 50(9), 2457-2461, doi:10.1016/j.enconman.2009.06.007, 2009a.

395 Khalifa, A. J. N. and Hamood, A. M.: Performance correlations for basin type solar stills, Desalination, 249(1), 24-28, doi:10.1016/j.desal.2009.06.011, 2009b.

Kopperdal, H. H.: Design , prototyping and field testing of solar stills in remote areas in Afghanistan, Norwegian University of Life Sciences., 2015.

Leong, G. C.: Certificate Physical and Human Geography, Oxford University Press, Hong Kong. [online] Available from: https://www.scribd.com/doc/309958147/Certificate-Physical-and-Human-Geography-by-Goh-Cheng-LeongAuthor, 1971.

Madhlopa, A.: Development of an advanced passive solar still with separate condenser, University of Strathclyde, Glasgow., 2009.

Morse, R. N. and Read, W. R. W.: A rational Basis for the Engineering Development of a Solar Still, Sol. Energy, 12, 5-17, 1968.

Muftah, A. F., Alghoul, M. A., Fudholi, A., Abdul-Majeed, M. M. and Sopian, K.: Factors affecting basin type solar still productivity: A detailed review, Renew. Sustain. Energy Rev., 32, 430-447, doi:10.1016/j.rser.2013.12.052, 2014.

Nafey, A. S., Abdelkader, M., Abdelmotalip, A. and Mabrouk, A. A.: Parameters affecting solar still productivity, Energy Convers. Manag., 41(16), 1797-1809, doi:10.1016/S0196-8904(99)00188-0, 2000.

410 Nafey, A. S., Abdelkader, M., Abdelmotalip, A. and Mabrouk, A. A.: Solar still productivity enhancement, Energy Convers. Manag., 42(11), 1401-1408, doi:10.1016/S0196-8904(00)00107-2, 2001.

Ogunseye, O., Adebomi-Omole, A. and Salami, S.: "Performance analysis of a basin-type solar still during harmattan - Raw Data", Mendeley Data, V1, , doi:10.17632/xhtnypxx6b.1, 2021.

Okeke, C. E., Egarievwe, S. U. and Animalu, A. O. E.: Effects of coal and charcoal on solar-still performance, Energy, 15(11), 1071-1073, doi:10.1016/0360-5442(90)90035-Z, 1990.

Onyegegbu, S. O.: Performance of photovoltaic cells in an equatorial climate, Sol. Wind Technol., 6(3), 275-281, doi:10.1016/0741-983X(89)90080-5, 1989.

Panchal, H. N. and Patel, S.: Effect of Various Parameters on Augmentation of Distillate Output of Solar Still: A Review, Technol. Econ. Smart Grids Sustain. Energy, 1(1), 1-8, doi:10.1007/s40866-016-0005-2, 2016.

420 Pfafflin, J. and Ziegler, E., Eds.: Environmental Science \& Engineering, Fifth., Taylor \& Francis, Boca Raton, FL., 2006.

Pillai, R., Libin, A. T. and Mani, M.: Study into solar-still performance under sealed and unsealed conditions, Int. J. LowCarbon Technol., 10(4), 354-364, doi:10.1093/ijlct/ctt045, 2015.

Qiu, G. and Riffat, S. B.: Optimum tilt angle of solar collectors and its impact on performance, Int. J. Ambient Energy, 24(1), 13-20, doi:10.1080/01430750.2003.9674898, 2003.

Sarkar, M. N. I., Sifat, A. I., Reza, S. M. S. and Sadique, M. S.: A review of optimum parameter values of a passive solar still and a design for southern Bangladesh, Renewables Wind. Water, Sol., 4(1), 1-13, doi:10.1186/s40807-0170038-8, 2017.

Sharma, V. B. and Mullick, S. C.: Analysis of heat transfer coefficients and evaporation in a solar still, Int. J. Energy Res., 16(6), 517-531, doi:10.1002/er.4440160609, 1992.

430 Talbert, S. G. and Eibling, J. A.: Manual On Solar Distillation of Saline Water, Washington D.C., 1970.

Tarawneh, K. and Muafag, S.: Effect of Water Depth on the Performance Evaluation of Solar Still, Jordan J. Mech. Ind. Eng., 1(1), 23-29, 2007.

Tiwari, G. N., Thomas, J. M. and Khan, E.: Optimisation of Glass Cover Inclination for Maximum Yield in a Solar Still, Heat Recover. Syst. CHP, 14(4), 447-455, 1994.

435 United Nations: Solar Distillation as a means of meeting small-scale water demands., 1970.

Velmurugan, V. and Srithar, K.: Performance analysis of solar stills based on various factors affecting the productivity - A review, Renew. Sustain. Energy Rev., 15(2), 1294-1304, doi:10.1016/j.rser.2010.10.012, 2011.

W.R McCluney: Solar distillation of Water, Cocoa., 1984.

World Health Organization: Guidelines for Drinking-water Quality, Fourth Edi., edited by World Health Organization, WHO Press, Geneva., 2011. 
https://doi.org/10.5194/dwes-2021-19

Preprint. Discussion started: 14 January 2022

(c) Author(s) 2022. CC BY 4.0 License.

Zarasvand Asadi, R., Suja, F., Ruslan, M. H. and Jalil, N. A.: The application of a solar still in domestic and industrial wastewater treatment, Sol. Energy, 93, 63-71, doi:10.1016/j.solener.2013.03.024, 2013.

Zeroual, M., Bouguettaia, H., Bechki, D., Boughali, S., Bouchekima, B. and Mahcene, H.: Experimental Investigation on a double-slope solar still with partially cooled condenser in the region of Ouargla (Algeria), in Energy Procedia, pp. 736-742, Elsevier Ltd., 2011. 